\title{
ONDERWYS IN AFRIKA
}

Vergelykende opvoedkundige studie: By 'n onderwerp soos die onderhawige, waarin dit gaan oor die onderwys van 'n groot aantal geweste wat baie van mekaar verskil t.o.v. politiek, ekonomie, ras, maatskaplike toestande, ens., moet daar noodwendig op die terrein van die Vergelykende Opvoedkunde getree word wat vandag reeds vaste oogmerke en metodes van ondersoek ontwikkel het. Wil ons dus enigsins aanspraak maak op wetenskaplikheid met ans onderwerp, moet ons die prose-

KOERS dure wat algemeen in toepassing is ook hier gebruik. Die agtergrondfaktore wat verantwoordelik is vir onderwysstelsels is:

a) Natuurlike faktore: ras, taal, geografiese en ekonomiese toestande.

b) Religieuse faktore: Rooms-Katolisisme, Protestantisme in talle variasies, Oosterse godsdienste in hulle variasies.

c) Sekulêre faktore: humanisme, sosialisme, nasionalisme, ens. 
Kom ons egter by die wese van die stelsel, dan is daar 'n groot aantal aspekte daarvan wat met mekaar vergelyk moet word, d.w.s. ons moet oor gegewens op daardie terreine beskik om ooreenkoms en verskil te kan aandui. Gebiede soos die volgende kom hier ter sprake: nasionale grondslag, onderwysdoel, beheer, finansies, administrasie en organisasie, onderwystrappe; voorskoolse, laer, middelbare, tegniese, hoër, onderwysersopleiding en -voorsiening, onderwysgeleenthede vir die bevolking as geheel, voertaal posisie, politiek en die onderwys, kultuur en die onderwys, verpligte skoolbesoek, gratis onderwys, geletterdheid, en nog talle meer.

Sonder betroubare gegewens op al bogenoemde terreine moet alle vergelyking noodwendig gebrekkig wees.

Probleme i.v.m. die vraagstuk aangaande die onderwys in Afrika:

Sover my kennis strek, is daar nog nooit 'n poging aangewend om so 'n uitgebreide terrein soos die vasteland van Afrika vergelykend opvoedkundig to behandel nie. Daar bestaan wel alge. mene inleidings oor die onderwys in Europa, in Asië, in Afrika, dog hierdie werke kom nie tot die werklike wetenskaplik deurgrondende behandeling van die probleem nie. Verder is daar deur verskillende persone en/of liggame gepoog om gegewens te versamel oor hierdie vraagstuk, soos lord Hailey en Unesco, dog hulle pogings verloop byna uitsluitlik in inventarisse, veral van die Unesco. Daarby verklaar hulle self dat die aangebode gegewens nie baie betroubaar is nie, om dan nie van die gevolgtrekkings wat daaruit afgelei word te praat nie. As voorbeeld van hierdie onbetroubare werk kan Hailey se slotsom oor die onderwystoestand in die Unie geld. Die onbetroubaarheid van die gegewens oor Afrika moet aan twee faktore toegeskryf word:

i). Die owerhede wat die "feite" verstrek (meesal statistiek) is self bewus daarvan dat hulle geen presiese syfers kan gee nie as gevolg van die onontwikkeldheid van groot dele van die bevolking, en

ii) die owerhede heg nie orals dieselfde betekenis aan dieselfde begrippe nie.

So word daar deur Unesco geskat dat daar in die wêreld ongeveer tussen 500 en 550 miljoen kinders van skoolgaande leeftyd is — ' $n$ speling van 50 miljoen wat nogal 'n aardige syfer is. En met onderwysgetalle in Afrika word daar veelal so gewerk. Verder verstaan al die gebiede byvoorbeeld nie dieselfde onder die begrip ,,geletterdheid" nie: vir party beteken dit iemand wat kan lees, vir ander iemand wat kan lees en skryf en vir nog ander iemand wat 'n sekere peil t.o.v. lees en skryf bereik het; en hulle statistiek word dienooreenkomstig opgestel. Wat word verstaan onder skoolleeftyd en skoolbevolking? Wat is primêre of elementêre onderwys, sekondêre onderwys, tegniese en hoër onderwys? Wat is die duur van die onderwys van hierdie verskillende trappe? En so kan voortgegaan word.

Die gegewens oor die onderwys in Afrika is baie onbetroubaar indien ons 'n deurtastende ondersoek dienaangaande wil instel. 
Maar daar is nog ander faktore wat ons taak haas onhanteerbaar maak. Afrika het vandag baie rasse en gebiede wat aardrylkskundig, ekonomies, staatkundig, kultureel, geweldig van mekaar verskil. Daar is Europeane, Oosterlin. ge en inheemse rasse wat aanmerklik van mekaar verskil; daar is woestyngebiede en vrugbare geweste, ryk en arm state, hoogstaande kulture en primitiewe gemeenskappe, selfstandige state en kolonies. Hoe sal ons hier anders kan vergelyk as om elke afsonderlike staat met al die ander te vergelyk? Dog dit kan onmoontlik binne die bestek van hierdie referaat val, afgesien van die onbetroubaarheid van die gegewens.

En tog is die prent nie heeltemal so duister as wat hier voorgehou word nie, mits ons kan begin elimineer om te kom by wat met hierdie groep inleidende artikels oor Afrika bedoel word. Ek meen ek is reg as ek die saak so interpreteer dat die liedoeling met hierdie artikelreeks is om die hooflig op die inboorling van Afrika te laat val. Ons skakel dan onderwystoestande op die kontinent vir sover dit die Europese inwoners betref uit. Terloops, die gegewens op hierdie terrein is seker die betroubaarste, dog in terme van Afrika vorm die blanke 'n kleine minimum. Nagenoeg orals word in sy behoeftes afsonderlik en goed voorsien. Verder kan ons die Indiërs uitskakel omdat hulle ewe-eens ' $n$ minimum is. Dit word, ten derde, vry algemeen aanvaar dat daar ' $n$ ingrypende verskil bestaan tussen Afrika Noord en Suid van die Sahara. Die dae van die Europese magte in Noord-Afrika is blykbaar getel, en vir die onderwys beteken dit dat die Europese onderwysbeleid daarmee saam sal verdwyn; waarskynlik sal daarop voortgebou word volgens die eie insig en behoeftes van die inheemse rasse. Hierdie groep kan ons dus feitlik beskou as onafhanklik of semi-onafhanklik wat langsamerhand eie onderwysstelsels sal bou. In Egipte is daar op hierdie terrein reeds tot 'n mate gevorder. Suid van die Sahara is daar slegs een volledig onafhanklike staat in terme van die onderwys gespreek en dit is die Unie. Elk neem aan dat ons hierdie gebied ook slegs hier en daar vergelykenderwys in ons probleem sal inbring. Vir sover dit die onderwys betref, is Ghana weinig meer as 'n koloniale gebied, en daarom skakel ons dit onder die koloniale gebiede in.

Vir die onderwysbeeld van Afrika is ons dan nou al baie ingeperk. Dit gaan in Afrika op onderwysgebied t.o.v. die naturel om die koloniale beleide van Europese state en met name van Engeland, Frankryk, België, Portugal en Spanje in orde van belangrikheid wat die inwonertalle betref.

\section{Onderwys in Afrika:}

a). Afrika en die wêreldonderwysbeleid:

Die „Universal Declaration of Human Rights," wat eenparig deur ongeveer 50 nasies tydens die derde sitting van die United Nations General Assembly op 10 Desember 1948 aanvaar is, stel in art. 26(1) „Everyone has the right to education. Education shall be free, at least in the elementary and fundamental stages. Elementary education shall be compulsory. Technical and professional 
education shall be made generally available and higher education shall be equally accessible to all on the basis of merit."

Hierdie hoë ideaal is by verre na nog nie met Afrika bereik nie. As ons op slegs 'n paar uitvloeisels van algemene onderwys vir almal let, word dit duidelik. Geletterdheid: Daar word geskat dat ongeveer $95 \%$ van die totale naturelle-bevolking van Afrika nie kan lees en skryf nie; die persentasie van die kinderbevolking op skool word op tussen $10 \%$ en $15 \%$ geskat; die vroulike geslag op skool haal nie $30 \%$ van die totaal nie; in die meeste geweste is die elementêre onderwys so kort van duur dat die leerling na sy skooljaar (-jare) nog analfabeet is, en $90 \%$ van die skoolgaande bevolking verkeer in sulke skole.

Die gebrekkige algemene toestand moet ongetwyfeld toegeskryf word aan:

(a) die koloniale beleide wat vir baie jare deur die Europese besitters gevolg is, nl. om die inheemse bevolking anders te bejeën as om hulle te kultiveer,

(b) die ekonomiese ontwikkeling van Afrika deur vreemde ondernemings,

(c) die bevolkingsaard,

(d) die lae vitaliteit van die inboorling as gevolg van siektes en klimaatsomstandighede, en

(e) die taalfaktor wat seker belangriker is as wat dit met de eerste oogopslag lyk. Ons kom later hierop terug.

In die jongste tyd het die imperialistiese teorieë en praktyke egter in onguns geraak, nie om filantropiese redes nie. Die eerste wêreldoorlog het Duitsland as koloniale mag uit Afrika laat verdwyn, die tweede Italië, maar nog belangriker is die posisie van Engeland en Frank- ryk, die belangrikste koloniale magte in Afrika, sedertdien in die wêreldpolitiek. Noodgedwonge moet nou aan die inboorling groter seggenskap in sy eie land se regering gegee word, en daarmee saam ook in die onderwys. Orals word daar pogings aangewend om nader aan die bostaande ideaal van die V.V.O. te kom. b). Kenmerke van die Afrikaanse onderwys:

Onderwysfasiliteite in Afrika is maar skraal, soos reeds vroeër geblyk het, en van die geringe geleenthede word nog ongereelde gebruik gemaak. Van die klein getalle wat nog die laerskool besoek, voltooi 'n minimum daardie kursus. Sekondêre skole is uiters skaars en hier en daar geleë - hierin loop die Unie ver voor in Afrika. Industriële en beroepsopleiding word sporadies en dan nog baie elementêr verskaf, hoofsaaklik deur plaaslike private ondernemings. Daar bestaan haas nêrens skoolplig nie, behalwe in 'n paar plekke plaaslik as eksperiment. Wat hoër onderwys betref, ontwikkel hier en daar geleenthede soos in Ghana, die Federasie, Frans Ekwatoriaal-Afrika, benewens die gevestigde universiteite in Egipte en Algiërs. Die inboorling is nog grootliks op buitelandse universiteite aangewys. Die vroulike geslag is orals minder op skool as die manlike, veral waar die Moslem-invloed sterk is. Slegs in party Suid-Afrikaanse geweste is die kaffertjies veewagters, en hier is dan meer meidjies op skool. Tog is die posisie van die vroulike geslag in die skool snel aan verander. In etlike geweste is getrag om die landbou te bevorder deur middel van landbou-onderwys en -voorligting, dog dit is steeds met 'n afsydige 
houding bejeën omdat landbou die vrou se werk is en die man dit dus nie wil leer nie. Orals word voorkeur aan akademiese onderwys gegee omdat dit lei tot administratiewe werk en die politiek. Hierdie houding is versterk omdat owerhede in die verlede die hoër primêre en die sekondêre onderwys gereserveer het vir die klein getal wat benadig word in die land se administrasic. Vandag het hierin heelwat verandering gekom deurdat die beleid sodanig verander is dat daar getrag word om op te lei vir plaaslike bevordering van landbou, ambagte, vir kontrole van siektes, voeding, uitroei van plae en peste, ens.

c) Onderwys in die verskillende koloniale gebiede:

Hieronder wil ons lrortliks nagaan die onderwysbeleid en -praktyk in die verskillende geweste beheer deur Engeland, Frankryk, België, Portugal en Spanje, sonder om op die besonderhede van elke kolonie in te gaan.

(i) Algemene beleid: Uit die koloniale onderwyspolitiek van die resente verlede blyk dit dat daar twee hoofrigtings wat as moontlikhede gegeld het, kan wees:

(1) Nadruk op die uitbouing van die beste elemente in die naturelle-kultuur en die ontwikkeling van die naturelleekonomie as 'n inheemse groei, en

(2) Nadruk op die Europese tipe onderwys en die assimilasie van die naturellebevolkings polities, ekonomies en kultureel in 'n eenheid waarin die Europese tutor-mag die nukleus vorm. Nie een van die twee kan absoluut wees nie, maar in soverre as wat verskille in nadruk duidelik is, lyk dit asof die Engelse politiek in die rigting van No. 1 geneig het, en die Franse en Belgiese in die rigting van No. 2. Die Portugese en Spanjaarde beskou hulle geweste nie as kolonies nie maar as inherente deel van die moederland en bind so die onderwys geheel en al aan die stelsel van die moederland.

Hierdie verskil in algemene politiek blyk duidelik uit die posisie van die moedertaal in die verskillende koloniale geweste. In die Engelse gebiede word daar veel meer waarde geheg aan die moedertaal op skool daarin dat dit die medium van onderrig in ùie aanvangsjare van die skool en by die volwasseneskool is. In die ander koloniale gebiede word die moedertaal nie as medium gebruik nie, dog die taal van die koloniale mag, behalwe in enkele uitsonderlike gevalle en dan slegs in addisionele onderrig of as plaaslike eksperimente. Vir elkeen van die twee standpunte is iets te sê. Die baie Afrikaanse tale en dialekte maak dit haas onmoontlik om van hulle almal geskrewe tale te maak en om ' $n$ bepaalde minimum handboeke beskikbaar te stel. Swahili maak die saak nog ingewikkelder deurdat dit 'n handelstaal is en vir baie heeltemal vreemd is sodat hulle eintlik naas die eie taal met twee vreemdes moet worstel. Dit is dan nog 'n ope vraag of die kind soveel verloor as hy van die begin af een van die wêreldtale, Engels of Frans, leer, en of hy nie in totaal daardeur veel meer wen nie.

Vroeë voorsiening vir onderwys in Afrika is deur die sendelinge gemaak in alle koloniale geweste van die kontinent, en in baie gebiede is hulle vandag nog die enigste voorsieners van skole. Volgens die algemene godsdienstige oortuiging van die moederland het die sending 
geskied: Rooms-Katoliek en/of Protestants. In die Engelse geweste oorheersend Protestantse sending, en in al die ander oorheersend Rooms-Katoliek. Whar in die jongste tyd die koloniale beleide neig tot groter staatsbeheer op haas alle terreine van die openbare lewe, het die kwessie van die sendingskool brandend geword, selfs in die Unie ook. Daar moes tot duidelikheid geraak word oor die posisie van hierdie skole. In sommige geweste is hulle invloed ingekrimp deurdat die staat self voorsiening gemaak het, en in ander is hulle deur dic staat finansieel in staat gestel om meer doeltreffende onderwys te verskaf. Veral in die oorwegend Protestan'se geweste raak die sendingskool op die agtergrond, terwyl die Rooms-Katolieke kerk so iets t.o.v. die onderwys nie duld in die geweste waar hy toonaangewend is nie.

Waar die Mohammedaanse invloed sterk is, is daar baie koranskole wat Ceitlik niks meer as 'n karikatuur vir 'n skool is nie. In sommige geweste word hierdic skole selfs deur die staat gesubsideer.

Op talle plekke bestaan daar „Company Schools" vir naturelle-werknemers of voornemende werknemers en hulle kinders.

, ii) Engrelse grebiede: Alhoewel die Britse owerheid ruim vryheid aan die kolonies laat t.o.v. onderwys, is algemene beginsels tog deur die Secretaries of State van tyd tot tyd vir almal bepaal. In 1924 is die Advisory Committee on Elucation in the Colonies in die lewe geroep wat in $1925 \mathrm{sy}$ eerste beleid i.v.m. onderwys in die kolonies neergelê het, nl. (a) ,..... that education should be adapted to the mentality and traditions of the various peoples, conserving as far ns possible all healthy elements in the fabric of their social life."

(b) Die grootste waarde moet geheg word aan godsdiens- en etiese onderrig

(c) Die effektiefste wyse om karakter te vorm, is die kosskool.

(d) Die belangrikheid van die onderwys van die vroulike geslag word beklemtoon.

(e) Alle pogings gebaseer op private inisiatief soos die van die sending word verwelkom, dog die reg word voorbehou om algemene beleid vir die onderwys te bepaal.

(f) Plaaslike adviesrade word aangemoedig.

In 1927 is weer dcur hierdie liggaam beleid bepaal en nou het dit hoofsaaklik gegaan oor die moedertaal in naturelle-onderwys: die moedertaal moet as medium gedurende die eerste skooljare dien, terwyl die waarde van die kennis van Engels in alle verdere onderwys beklemtoon is.

In 1930 word verklaar dat onderwys vir volwassenes ewe onontbeerlik is.

In 1943 word bepzal dat jeugdige, adolessente en volwassene-onderwys beskou moet word is een groot geheel in die program van massa-onderwys. Hierin word beoog dat mettertyd primêrc onderwys uitgebrei moet word na almal en dat alle volwassenes onder 50 jaar oud geletterd moet word. Daar moct ook mettertyd vir hoër onderwys voorsiening gemaak word.

Gedurende die tydperk 1.4.1946 tot 31.3.1954 is vir die vyftien Afrikaanse 
kolonies geld bestee aan onderwys soos volg:

Vir primêre en sekondêre onderwys

Vir tegniese en beroepsonderwys

Vir hoër onderwys insluitende beurse

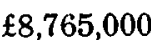

Die algemene beleid waarvan hier gepraat word, het nie uniformiteit in al die gebiede op die oog gehad nie; plaaslike ontwikkeling moes juis ' $n$ eie koers inslaan. So het die regerings van Uganda en Niasaland verkies om grootliks op sendingliggame te steun terwyl Zanzibar en die Tanganjika-kusgebied grootliks van staatsonderwys gebruik maak. In die noordelike provinsies van Nigerië het die plaaslike naturelle-owerhede in 1951397 uit die totaal van 1,121 primêre skole voorsien en daarby nog fondse vir 11 sendingskole ook beskikbaar gestel. In die noordelike gebiede van die Goudkus oortref die naturelleowerhede se skole die sendingskole ver in getal, en daar is tans ook 'n groeiende aantal sulke skole in Sierra Leone; ook in Kenia is daar ' $n$ aansienlike aantal plaaslike Naturelle-Raad-skole. In Noord-Rhodesië beheer die staat direk tegniese onderwys in stedelike gebiede, in die plattelandse gebiede word dit deur die sending beheer; in meeste ander gebiede word alle tegniese onderwy's deur die staat beheer. Daar is groot variasie in die mate van kontrole wat die staat uitoefen oor die skole wat nie direk onder sy beheer staan nie, soos die sendingskole en naturelle-owerhedeskole. Vandag moet omtrent orals van staatsweë toestemming verkry word om skole op te rig en in alle gevalle word dan ook sekere minimum-vereistes aan sulke skole gestel.

Sommige geweste nader nou 'n stelsel van universele onderwys. Skoolbesoek is tans verpligtend gemaak vir Asiateseuns in Nairobi, Mombassa en Kisumu. In Niasaland en Tanganjika is inskrywing opsioneel, maar die bywoning van leerlinge wat eenmaal ingeskryf is, is verpligtend. Noord-Rhodesië het in 1943 verpligte onderwys ingevoer vir Broken Hill, Ghoma en Livingstone vir kinders tussen 12 en 16 jaar wat binne 3 myl van ' $n$ skool af woon. Om verpligte skoolbesoek 'n sukses te maak, moet daar skoolbesoekbeamptes wees en dis maar ' $n$ probleem in Afrika.

In gebiede met 'n gemengde bevolking word op verskillende wyses vir elke groep voorsiening gemaak. In Tanganjika is in 1948 afsonderlike fondse in die lewe geroep vir blanke en Asiate-onderwys en dit is geadministreer deur blanke en Asiate-onderwysowerhede. Verder is daar advieskomitees vir naturelle en ander nie-naturelleonderwys in die lewe geroep. In Uganda en in Kenia is daar afsonderlike adviesrade vir naturelle, Asiate en blanke-onderwys. Daar bestaan vandag maar 'n klein aantal primêre en sekondêre skole wat oop is vir lede van meer as een ras. Basterkinders word in staatsblankeskole in Kampala toegelaat mits hulle huislike agtergrond Europees is. Die universiteitskolleges is oop vir alle rasse.

Daar word baie kritiek uitgespreek teen die huidige stelsel in die Britse kolonies: teen die rol wat die Britse eksterne eksamens speel; oor die gebrek 
van voorsiening van onderwys vir die vroulike geslag; die boekgeleerdheid van die skole; die hoë koste verbonde aan die onderwys van blankes. Een van die belangrikste struikelblokke in die weg van die oorkoming van hierdie probleme is die sterk teenstand van die kant van die naturelle teen die idee om aan hulle ander onderwys te gee as aan die blanke. Daar word tans vinniger skole opgerig en nou kom die beswaar weer dat dit die standaard van die onderwys sal verlaag.

Deurgaans bestaan daar 'n baie sterk behoefte aan onderwys by die naturel, en selfs die armstes onder hulle is bereid om op te offer in hierdie verband. Die belangrikste hinderpaal in die weg van universele onderwys is die tekort aan onderwysers. Op die huidige oomblik vorder slegs $10 \%$ van die leerlinge verder as die primêre skool.

(iii) Franse gebiede: In die Franse gebiede vind ons net soos in die Engelse ooreenkoms met die tuisland se onderwysstelsel. Die Engelse is in wese 'n gedesentraliseerde en daarom hulle kolonies s'n ook; die Franse is in wese 'n gesentraliseerde en daarom hulle kolonies s'n ook. Die Franse kolonies se onderwys is in soverre gedesentraliseer dat elke geweste se probleme die verantwoordelikheid van die plaaslike openbare onderwysdiens in die oorsese gebiede is. Algemene onderwysbeleid, veral t.o.v. leerplanne, eksamens en die status van die onderwyser, moet op 'n regeringsvlak opgestel word. Almal in die verskillende geweste is geskakel met die Ministerie van Nasionale Onderwys in Frankryk.
In elke oorsese gebied word die onderwys georganiseer om aan te pas by die plaaslike behoeftes, dog die werklike patroon van die skole neem meer en meer die vorm aan van die skole van die moederland. Die leerplanne neergelê in die dekrete van die gewestelike goewerneurs kom ooreen met of is gelyk aan die neergelê deur die Ministerie van Nasionale Onderwys in Frankryk; ook die eksamens is gelyk aan die van die Franse skole. Hierin werk die naturelle saam deurdat hulle die Franse onderwysstandaard ook vir hulle kinders begeer. Die plaaslike owerhede se taak is dan feitlik net om die moederland se onderwysmetodes aan plaaslike behoeftes aan te pas. Die eksamens wat afgelê word, die diplomas wat uitgereik word en die tipes skole wat opgerig word, stem alles ooreen met die van Frankryk; ook die privaatskole (sending) voer hierdie beleid uit en hulle is steeds onderhewig aan inspeksie. Tog bestaan daar in die geweste met sterk Mohammedaanse invloed ook Koranskole wat uiters elementêr is. Die beleid is egter om uniformiteit in alle Franse geweste t.o.v. die onderwys te verkry om daardeur die Franse kultuur op Afrika oor te plant, en een van die sterkste instrumente ter bereiking van hierdie doel is die aanwending van Frans as medium van onderwys op alle vlakke van die onderrig. Daar is dus weinig variasie in die verskillende Franse geweste.

Ons kan tot die volgende slotsom kom:

"Though education in the overseas territories retains its own highly decentralized organization, which allows for adaptation to local conditions and would 
permit it, should the need arise, to take highly individual forms, it is more and more approximating, by its methods, the standards of its work, the efficiency of its staff and the broadly humanistic outlook which inspires it, to that of the home country. It is French culture which is being spread in the primary schools, the lycées and the colleges of the overseas territories, and this fact constitutes one of the firmest links uniting them to the rest of the Republic."

(iv) Belgiese gebiede: die jaar 1948 vorm 'n belangrike mylpaal in die onderwys van die naturel in Belgies-Kongo. Voor daardie jaar het alle onderwys in die teken van die opleiding van die werker vir die landsekonomie gestaan, en hierin het die naturel veel skade gely. Sedert 1948, toe 'n 10-jaarplan in werking gestel is, is daar veel dieper getas met die onderwys, sodat opheffing van die naturel in die voorgrond gestel is. In teëstelling met die Fransman wat die naturel soveel moontlik met die die Europese beskawing wil assosieer, beoog die Belg met hom 'n vollediger ontwikkeling binne die omvang van sy eie ekonomiese en sosiale omgewing. Die Kongo het 'n rykdom van latente bronne, en die regering beywer hom om die bevolking intelligent te ontwikkel as hulp in die ontginning van hierdie bronne. Die doel van die onderwys is om beter naturelle te produseer en nie modelle van Europeane wat nooit meer as derdegraadse mense sal wees nie. Op grond hiervan word daar dan ook 'n onderwysbeleid en -organisasie gehandhaaf wat grootliks verskil van die van die moederland.

Moedertaalonderwys word in die laer- skool toegepas, en i.p.v. 'n algemene onderwys word groter klem op onderrig met 'n praktiese en beroepskundige inslag gelê.

(v) Portugese gebiede: Deur 'n wet van 1951 is die status van elk van Portugal se besittings verander van die van kolonie na die van oorsese provinsie. Hiermee is die Afrikaanse gebiede baie nou verbind aan die moederland en alles wat daarmee in verband staan. In die onderwys word blykbaar definitief daarna gestreef om die naturel te laat kwalifiseer vir die status van die Europeaan of altans van die Europeaan soos die Portugees hom beskou. Gevolglik word geen waarde geheg aan Afrikaanse instellings nie, van moedertaalonderrig is daar geen sprake nie en naturelle het toegang tot alle skole.

(vi) Spaanse gebiede: Geringste van alle koloniale magte. Die beleid skakel ten nouste saam met die moederland.

(vii) Algemene Onderwysinrigting: Alhoewel daar heelwat verskil op hierdie gebied bestaan, meen ek tog dat ons 'n algemene beeld kan probeer saamstel. In alle lande is daar variasies dog in die groot geheel geneem, kom die onderwysinrigting op die volgende neer:

a) Administrasie: In al die Afrikaanse geweste bestaan daar departemente van onderwys - by party ingeskakel by naturellesake, by ander selfstandig met ' $n$ amptenaar aan die hoof, meesal 'n direkteur genoem, en 'n inspektoraat wat die staatskole beheer en 'n mate van kontrole uitoefen oor die privaatskole. Die sendingskole wat in meeste lande die meerderheid skole uitmaak, hou 'n eie administrasie daarop na. Die finansiering van die onderwys geskied 
gedeeltelik deur die staat en gedeeltelik deur die sending en plaaslike bydraes van die naturellegemeenskap. Daar kestaan dan ook in talle geweste plaaslike naturellerade, party met slegs adviserende magte, ander met beheermagte. Onderwys is dus feitlik orals sterk gedesentraliseer wat die administrasie daarvan betref.

b) Organisasie: Die laerskooltydperk beslaan in die reël 6 tot 8 jaar - alhoewel daar baie skole bestaan wat nie meer as twee of drie jaar onderwys verskaf nie - en hierin word die gewone vakke van die laerskool aangebied met besondere klem op praktiese werk en landbou. In die Engelse en Belgiese gebiede word die moedertaal as medium in hierdie skole gebruik, terwyl die ander die moederland se taal as medium geld. In die moedertaalskole word die moederland se taal langsamerhand ingevoer as vak. In die koranskole, wat haas nie as skole kan geld nie, word daar grootliks gedeeltes uit die Koran gememoriseer en die taal is Arabies. Die sekondêre skole is feitlik deurgaans geskoei op die lees van die moederland, gebruik as medium die moederland se taal en berei kandidate voor vir die hoër onderwys in Afrika of in die moederland. Beroepskole is orals skaars, dog hierop word in die jongste tyd sterk gekonsentreer. Hoër onderwys is grootliks bekombaar in lande buite die koloniale gebiede, alhoewel daar enkele universiteite beskikbaar is soos Makerere-kollege, Universiteitskollege van die Sentraal-Afrikaanse Federasie, Universiteit van Algerië. Daar word ook langsamerhand vordering gemaak met onderwys vir volwassenes. Die oorgroot meerderheid leerlinge bevind hulle in die aanvangsklasse van die lacrskool.

c) Onderwysersopleiding: In al die gebiede bestaan daar ' $n$ nypende tekort aan onderwysers. Hierdie lande staan in hulle kinderskoene wat die onderwys betref, en met die verskerpte benadrukling van die reg van elke mens tot onderwys, spreek dit vanself dat dit die toestend wat die onderwysers betref nog vir baie jare sal bly. Die staat en die sending lei onderwysers op vir verskillende tipes skole on die groot gros skole moet tevrede wees met swak gekwalifiseerdes as gevolg van die noodtoestand. In die Franse gebiede word getrag om die eise vir onderwysersopleiding op dieselfde peil as die van die moederland te bring, dog die werklikheid is baie ver daarvandaan.

d) Probleme: Uit wat onder die onderwysinrigting gesê is, is dit duidelik dat met talle probleme geworstel word wat die onderwys in Afrika betref :

1. Dit is 'n stryd om die naturel vir 'n redelike tyd op skool te hou.

2. Die taalkwessie is uiters moeilik, veral as gedink word aan die probleem met handboeke.

3. Onderwysersvoorsiening kom onoplosbaar voor.

4. Die finansiële laste is ondraaglik groot as voorsiening vir 'n redelike mate van onderwys gemals moet word as gevolg van die algemene ekonomiese agterstand van Afrika.

(viii) Uitkoms van die onderwys: Die vraag kom nou onmiddellik na vore: Wat word bereik met die onderwys? Els het getrag om 'n tabel op te stel oor die skoolinskrywing in die verskillende 
geweste van Afrika, dog die gegewens is so onbetroubaar en daar word op so 'n verskeidenheid van maniere indelings van skole en leerlinge gemaak, dat dit oninoontlik geblyk het. In breë trekke kom die toestand na skatting hierop neer:

1. Van $75 \%$ na $95 \%$ van die naturellebevolkings van Afrika is vandag nog analfabete.

2. Van $10 \%$ tot $15 \%$ van die kinders van skoolgaande leeftyd, d.w.s. tussen 7 en 14 jaar, bevind hulle op skool.

3. Van $60 \%$ af op van die skoolgaande kinders kevind hulle op die laerskool en van hulle is ongeveer $80 \%$ in die eerste twee jaar von hulle skoolopleiding. Hierdie saak mag nie so beskou word asof dit tans eers vir hulle moontlik geword het om die skool te besoek nie, dog veel meer dat hulle om 'n verskeidenheid van redes nie langer op skool bly as ongeveer twee jaar nie.

4. Die geringe persentasie learlinge in die middelbare skole bevind hulle in die laer standerds van die middelbare skool.

5. Nog minder leerlinge geniet ambags- en tegniese onderwys; in party geweste is die onderrig so elementêr dat dit haas nie onder hierdie benaming geklassifiseer kan word nie.

6. Die persentasie wat hoër onderwys ontvang, is nog geringer as die wat ambagsonderwys ontvang.

Ons slotsom is dat Afrika nog baie ver van die oogmerk van Unesco af is.

(ix) Onderwys in Afrika en die toekoms: In die eerste paragraaf het ons opgemerk dat die Vergelykende Opvoedkunde die agtergrond van 'n onderwys- stelsel bestudeer om tot 'n duidelike kegrip van die wese daarvan te kom. In die geval van die onderwys in Afrika sou dit beteken dat die primitiewe naturelle-kulture bestudeer sou moes word indien hierdie volkere 'n normale ontwikkeling deurgemaak het wat hulle onderwys betref. Ek het gekorrespondeer met al die verskillende onderwysdepartemente in Afrika en nie een van hulle was in staat om gegewens i.v.m. die inheemse onderwysstelsel van hulle state te verstrek nie. En al sou hulle kon, sou dit vir hierdie studie nie veel waarde hê nie, omdat die georganiseerde onderwys van vandag nie daaruit ontwikkel het nie. Hier en daar is nog reste van die stamskole oor by die naturelle- en koranskole by die Mohammedane, dog hulle kan nie in die volle sin van die woord as onderwysinrigtings beskou word nie - altans nie in die sin wat in die moderne lewe aan die term geheg word nie.

Georganiseerde onderwys in Afrika vind sy agtergrond in Europa en wel in die lande wat as koloniale magte opgetree het. In hierdie referaat is dan ook meer as een keer daarna verwys dat wat in bepaalde geweste op onderwysgebied plaasvind in breë trekke in ooreenstemming is met wat in die moederland op hierdie gebied in toepassing is. Met die kersteningspoging van Afrika deur die sending in alle state het die Europese onderwys gekom, en as kultuurproduk het dit ook die Europese kultuur en tale hierheen gebring. Deur party lande soos Frankryk, Portugal en Spanje is getrag om die naturel 'n Europeaan te maak, terwyl Engeland hom daarop toegelê het om aan te sluit 
by wat in die Afrikaanse naturellekultuur nie in botsing met algemene gekultiveerdheid is nie, en vandaar uit te bou aan 'n eie Afrikaanse kultuur onder leiding van die Europese. Die eerste groep stamlande se opvatting is o.i. verkeerd omdat dit noodwendig moet lei tot geestelike en kulturele ontstamming van die naturel wat hom 'n ongelukkige wese laat wat nooit Europeër in die volle $\sin$ van die woord word nie, en hom ook nie meer ten volle kan inleef in sy eie Afrikaanse grondslag nie. Vir ons kan slegs die standpunt van Engeland gedy. In hierdie verband sou ons voorbeelde kan noem wat daarop dui dat in die Engelse kolonies ook denasionalisering van die naturel beoog is, dog dit kan nie as die algemene Engelse beleid beskou word nie.

Die toekoms van die onderwys in Afrika is in die weegskaal, en daaroor sal nie deur die Westerse blanke lande beslis word nie. Die naturel sal self daaroor beslis, en hy wil - - onder invloed van die Westerse lande in die verlede en vandag nog ten dele, dog grootliks onder Russiese leiding - niks anders en niks minder as die onderwys van die moderne beskawing hê nie. In sy land het hy geleer dat diegene wat oor die wel en die wee van die volk beskik die blanke onderwys besit. En hierdie omwenteling van sy lewe in al sy aspekte sal hy self op sy eie manier assimileer. Onder die kreet van die regte van die mens bekom hy onafhanklikheid soos Ghana op 'n stadium waarop sy bene nog nie sterk genoeg is om die toegekende verantwoordelikhede te dra nie, maar hy deins nie daarvoor terug nie. Ghana het 'n uitgebreide onderwysprogram waarin alles op die spel geplaas word om daardeur die nodige peil van ontwikkeling te bekom. En hy betaal ten duurste daarvoor. So word talle gegradueerde Bantoe-onderwysers vanuit die Unie gerekruteer teen salarisse wat ons blanke onderwysers sal laat watertand. 'n Eertydse naturelleskoolhoof van Potchefstroom het 'n aanbod om daar te gaan skoolhou teen 'n salaris wat loop tot nagenoeg $\mathfrak{£ 2 , 5 0 0}$.

In hierdie kultuur-omwenteling of -rewolusie wat in Afrika aan die afspeel is op onderwysgebied is daar egter geweldige probleme wat die naturel sal moet oplos, en die vraag is of hy hiertoe opgewasse is. Mens wonder dan of Engeland, Frankryk, België, Portugal en Spanje nie mettertyd uit Afrika uitgeskakel sal word soos eertyds Duitsland en Italië nie, en of daar dan nie 'n nuwe vorm van „kolonisasie" sal aanbreek onder die leiding van Rusland om te doen wat die naturel nie selfstandig kan doen nie.

In die Unie beleef ans ' $n$ nuwe bedeling wat die onderwys van die Bantoe betref wat t.o.v. sy ontwikkelingsmoontlikhede deur geen ander Afrikaanse geweste geëwenaar word nie. Daar word nog by die ou beleid gehou, nl. om die Bantoe in sy eie kultuur op te voed, dog hierby word die Europees-Christelike ingeskakel. Dwarsoor die land bestaan daar 'n eenheidsbeleid en -beheer van onderwys waarby die Bantoe in die beheer en finansiering ten nouste betrek word - dinge waarop die blanke hier te lande met reg jaloers kan wees - omdat hy dit self nie besit nie. Alhoewel dit 'n langtermynbeleid is -- soos enige onder- 
wysstelsel behoort te wees - sal daar waarskynlik mettertyd 'n stadium bereik word waarop die Bantoe op gelyke voet met die blanke sal verkeer. Dan sal daar aparte Afrikaanse blanke en Bantoestate geskep moet word as daar verder vrede moet wees.

H. J. J. BINGLE.

P.U. vir C.H.O.

'N PAAR BRONNE.

1. Bantoe-onderwyswet 1953 . Unie van Suid-Afrika.
2. N. de Cleene et al: Lezingen over de Ouvoeding der Plattelands-bevolking in Belgisch-Kongo; 1951.

3. Lord Hailey: An African Survey; Revised 1956. Africa South of the Sahara.

4. Moehlman and Roucek: Comparative Education. Africa; 1952.

5. Unesco: World Survey of Education; 1955.

6. Persoonlike korrespondensie met Afrikaanse State se departemente van onderwys. 